\title{
Financial Reporting Behaviour and Firm's Economic Success: Malaysian Evidence
}

\author{
NOR IRDAWATI MAHYUDDIN, HAIRUL SUHAIMI NAHAR \& YUSNIYATI YUSRI
}

\begin{abstract}
The emergence of modern corporate landscape, with regard to the way firms are managed and controlled, creates a variety of financial reporting issues. Empirical results in prior studies have been inconclusive, as to whether financial reporting behaviours i.e. earnings management activities are detrimental to firms' economic success (proxied by its future performance). Some have argued that managing earnings are intended to achieve better future performance rather than being opportunistic in nature. This study aims to empirically investigate whether managing earnings to meet earnings target has any affect on firms' future performance in Malaysia. In extending prior work in the earnings management area, by incorporating discretionary reporting behaviour element to provide better view of Malaysian firms' financial reporting behaviours across 2001-2015 reporting horizon, we find that real-based earnings management led to lower firm's future performance. This supports the agency theory prediction that firms which engage in real reporting opportunistically would negatively affect their future economic performance. This, however, does not hold true for accruals earnings management. The empirical results suggest that different mechanisms of financial reporting behaviour, of either discretionary or real in nature, provide different implications on the firms' future performance. The paper adds to the growing body of empirical knowledge in financial reporting behaviours and firms' economic success in an emerging economy like Malaysia.
\end{abstract}

Keywords: Real and Accrual Earnings Management; financial reporting behavior; firm's future performance.

\section{INTRODUCTION}

Financial accounting information plays an informative role to the users of financial statements. It is used in evaluating whether resources have been efficiently allocated, firms are able to repay loans and are capable of generating positive returns in the future. Investors and analysts use financial information to evaluate equity prices (Embong \& Hosseini 2018), reinforcing the importance of having a reliable source of financial information of firms. Earnings are found to provide invaluable information. Prior studies have provided evidence that earnings affect organisational efficiency (Ab-Hamid, Asid, Che Sulaiman, Wan Sulaiman, \& Abdul Bahri 2018) and investors react to earnings announcement (Ball \& Brown, 1968; Kangai, Kiremu, \& Box, 2013; Mlonzi, Kruger, \& Nthoesane 2011) where market reward firms with higher earnings. As such, managers are under immense pressure to achieve the targeted earnings, as well as, to maintain the level of earnings. This could provide the motivation for managers to manage earnings.

Most of the prior earnings management (EM) studies tend to lean towards the opportunistic notion when investigating the incentives and occurrence of certain events (Adut, Holder, \& Robin 2013; Rahman, Hassan, Saleh, \& Shukor 2013; Shette, Kuntluru, \& Korivi 2016). EM is defined as a process where managers 'use judgment in financial reporting and in structuring transactions to alter financial reports to either mislead some stakeholders about the underlying economic performance of the company or to influence contractual outcomes that depend on reported accounting numbers' (Healy \& Wahlen 1999, p. 368). Nevertheless, no consensus has been achieved as to whether EM is opportunistic or beneficial. Opportunistic is often described as being in line with the agency theory, where management is perceived to have private information and use it to maximise their own wealth (Kouaib \& Jarboui 2014). There is evidence of abuses of accruals and premature revenue recognition, as well as, big bath and 'cookie jar' reserves (Altamuro, Beatty, \& Weber 2005; Jordan \& Clark 2011; Nieken \& Sliwka 2015; Omar, Rahman, Danbatta, \& Sulaiman 2014), which pose a threat to the quality of financial reporting. The informative perspective, however, argues that managers exercise discretion over earnings to enhance information and convey private information (Arya, Glover, \& Sunder 2003). This would enhance the value of the firms and their shareholders (Al-Shattarat, Hussainey, \& Al-Shattarat 2018; Gunny 2010; Jiraporn, Miller, Yoon, \& Kim 2008).

Prior studies have found that there are too many firms that are operating either above or below the earnings threshold. There is also evidence to suggest that firms have strong incentives to manage earnings to avoid losses or earnings reduction from previously achieved figures (Brown \& Caylor 2005; Degeorge, Patel, \& Zeckhauser 1999; Ebaid 2012; Halaoua, Hamdi, \& Mejri 2017; Kao 2014). Accordingly, this study aims to empirically investigate whether managing earnings to meet earnings target has any affect on the firms' future performance in Malaysia. Malaysia is a unique research setting, being an emerging economy with distinctive institutional setups, governance attributes and vibrant equity market. These attributes are arguably dissimilar to those in advanced economies, which was the focus of prior EM studies. Contrastingly, different from prior Malaysian EM studies (Ab-Hamid et al. 2018; Abdul Rahim \& Nelson 2018), this study uses a multiple regression method on 227 Malaysian listed firms from 2001-2015 and finds firms that just meet the earnings benchmark (avoid losses and earnings decline), either via accrual and real earnings management activities, have lower future 
performance. Furthermore, if these firms managed earnings via real earnings management (REM) to just meet the earnings benchmark will have an even lower future performance. This study also finds that firms missing/beating the earnings benchmark but engage in REM have better future performance suggesting that firms utilise REM activities to convey private information. However, no evidence is found for firms managing earnings via discretionary accruals (DA).

The paper is organised as follows: the next section will discuss on the literature review and hypothesis development. This is followed by the methodology and the empirical results sections. The final section concludes the paper.

\section{LITERATURE REVIEW AND HYPOTHESIS DEVELOPMENT}

The agency theory is largely concerned with the relationship between the principals and agents. The agent is a professional person who is hired by the principal (the owner), to manage and perform tasks on the principal's behalf. This theory posits that, as the owner appoints professional management to run the business, the decision and power to manage the business is transferred to the management without having to bear any of the consequences of their decisions (Chen \& Jaggi 2000; Fama 1980; Jensen \& Meckling 1976). Due to the sizeable separation between ownership and management, there are underlying assumptions that could lead to the agency problem. Since both the principal and the agents are utility maximisers, the interests between the owners and the managers may not be always aligned (Jiraporn et al. 2008). As such, there is a high possibility that the goal of maximising shareholders wealth could be overlooked, instead, to maximise the self-interests of management.

Prior studies have found that market places great expectations on firms with high growth (Gabrielsen, Gramlich, \& Plenborg 2002) and that firms are heavily penalised when they missed their targeted earnings (Skinner, Sloan, \& Hand 2002) As such, firms are motivated to maintain their growth performance and more likely to manipulate their earnings. Shareholders run the risk of experiencing negative long-term economic consequences. Kim and Sohn (2013) find evidence that firms which use REM to meet or beat earnings benchmark resulted in the increase of its cost of equity.

Prior studies have also found that firms which manage earnings opportunistically will have negative long term consequences, for instance, when issuing initial public offering (IPO) (Kalgo, Nordin, Nahar \& Turmin 2016; Teoh, Welch, \& Wong 1998) and seasoned equity (Cohen \& Zarowin 2010; Kothari, Mizik, \& Roychowdhury 2016; Shu \& Chiang 2014). Eldenburg, Gunny, Hee, and Soderstrom (2011) also finds a negative relationship between REM and future performance when compensation is attached to performance. In addition, firms are also found to have poorer performance when practicing earnings management as it deviates from optimal discretionary expenses activities (Leggett, Parsons, \& Reitenga 2016). This include using sales manipulation, production manipulation and discretionary expenses simultaneously (Cupertino, Martinez, \& Costa Jr 2016; Nera, Manurung, \& Murwaningsari 2017; Tabassum, Kaleem, \& Nazir 2015)—supporting opportunistic view from the agency theory.

Signalling theory, on the other hand, suggests that firms manage earnings as a way to signal firms' future performance (Al-Shattarat et al. 2018). It is argued that managers possess additional information about the firms' markets and growth potentials. As such, engaging in EM to meet the earnings benchmarks may enhance firms' credibility and reputation with stakeholders (Bartov, Givoly, \& Hayn 2002; Burgstahler \& Dichev 1997). This is evident when Jiraporn et al. (2008) finds a positive relationship between DA and firm value. Furthermore, Gunny (2010), Mohd Suffian, Mohd Sanusi, and Matsuki (2015) and Al-Shattarat et al. (2018) are also in support of the signalling argument; that firms use REM to signal potential good performance. They find a positive relationship between firms managing earnings upwards via REM to meet earnings benchmark and future performance. Similarly, Sutrisno (2017) investigates the consequences of DA and REM on firms' future performance and find that firms which manage its' accruals and sales enhance its' subsequent operating cashflows, supporting the notion that EM activities effectively benefit the firms.

Given these two competing views, the direction of the relationship is inconclusive. As such, this study hypothesises that:

$\mathrm{H}_{1}$ : There is a significant relationship between firms that manage earnings to meet the earnings benchmark and future performance.

\section{RESEARCH METHODOLOGY}

\section{SAMPLE SIZE}

A total of 227 firms listed on Bursa Malaysia's main market, with complete financial data, auditors, and ownership variables from 2001 to 2015, were selected. This is to accommodate the balanced data and balanced-period research design to achieve objectivity in the assessment procedures. This study employs secondary data, which were obtainable from the two main sources; financial database and companies' annual reports. All financial data were downloaded using the Thomson Financial DataStream database. Any missing figures from DataStream were acquired from the annual reports. Data were randomly checked with annual reports to enhance data accuracy. In order to provide a more detailed analysis, firms are then classified into 1) firms that just meet the benchmark (i.e. avoid losses and earnings decline) - referred to as "meet", and 2) others. As 
such, the dummy variable for "meet" is set to 1 if the net income divided by total assets is between 0 and 0.01 or the change in earnings per share (EPS) from $t$ and $t-1$ is between 0 and 0.01 . Otherwise, it will be set to 0 .

\section{VARIABLES MEASUREMENT}

The application of the regression model requires the specification of the dependent variables (DV) and independent variables (IV) to be determined. Based on the hypothesis developed, future performance is set as the DV while EM is set as the IV. This study will look at two EM metrics; REM and DA.

\section{REAL EARNINGS MANAGEMENT (REM)}

This study follows Roychowdhury (2006) and Zang (2012) in developing the REM proxies. It comprises of:

1. Sales manipulation measured by abnormal cash flow from operation (ASM),

2. Production manipulation measured by abnormal production costs (APROD), and

3. Discretionary expenses manipulation using abnormal discretionary expenses (ADISX).

Sales manipulation is defined as managers' efforts to temporarily increase the volume of sales. This can be achieved by providing discounts on the sales items and a more lenient credit term. Although the sales have increased (which led to increase in the current earnings), the gross margin will be lower, which will result in lower cash flows. To capture this, the normal cash flows from operations (CFO) and abnormal CFO are generated. Based on Roychowdhury (2006), the normal $\mathrm{CFO}(\mathrm{NCFO})$ is computed as follows:

$$
\frac{C F O_{t}}{A_{t-1}}=\alpha_{0}+\alpha_{1}\left(\frac{1}{A_{t-1}}\right)+\beta_{1}\left(\frac{S_{t}}{A_{t-1}}\right)+\beta_{2}\left(\frac{\Delta S_{t}}{A_{t-1}}\right)+\varepsilon_{t}
$$

Where,

$C F O_{t}=$ cash flows from operation for the year $\mathrm{t}$,

$A_{t-1}=$ total assets at the end of the previous year, $\mathrm{t}-1$

$S_{t} \quad=$ sales during the year $\mathrm{t}$

$\Delta S_{t}=$ change in sales [(Salest) - (Salest-1)]

A regression is run cross-sectionally for industry years with at least 8 firms in each industry. The abnormal CFO (ASM) is computed by deducting the NCFO (computed using the estimated coefficients from (1)) from the actual CFO.

Firms can also attempt to lower its costs of sales to increase their gross margin and hence increasing their reported earnings. This can be achieved through overproduction, lowering the cost of goods sold (COGS) via fixed cost. However, overproduction can cause firms to incur additional holding cost and very likely to increase the marginal costs relative to the sales. As such, the level of cash flows will be lower than the normal sales levels.

Cost of production is defined as COGS plus any changes in inventory during the year. Following Zang (2012), the normal productions cost (PROD) is estimated as follows:

$\frac{P R O D_{t}}{A_{t-1}}=\alpha_{0}+\alpha_{1}\left(\frac{1}{A_{t-1}}\right)+\beta_{1}\left(\frac{S_{t}}{A_{t-1}}\right)+\beta_{2}\left(\frac{\Delta S_{t}}{A_{t-1}}\right)+\beta_{3}\left(\frac{\Delta S_{t-1}}{A_{t-1}}\right)+\varepsilon_{t}$

Where,

$P R O D_{t}=$ COGS $+\triangle$ Inventory for the year $\mathrm{t}$,

$A_{t-1}=$ total assets at the end of previous year, $\mathrm{t}-1$

$S_{t} \quad=$ Sales during the year $\mathrm{t}$

$\Delta S_{t} \quad=($ Sales for the year $\mathrm{t})-($ Sales for the year $\mathrm{t}-1)$

$\Delta S_{t-1}=($ Sales for the year $\mathrm{t}-1)-($ Sales for the year $\mathrm{t}-2)$

The estimation is regressed cross-sectionally for industry years. The abnormal level of production (APROD) is measured by deducting the normal PROD () from the actual PROD.

Managers may also decide to reduce discretionary expenses in order to increase firms' earnings. The discretionary expenses include expenses related to research and development (R\&D) activities, selling expenses, as well as, general and administrative expenses (SGA) which includes employee training, travel and maintenance. below:

Following Zang (2012), lagged sales value is used and derive the normal discretionary expenses as in the equation 
$\frac{\operatorname{DISEXP}_{t}}{A_{t-1}}=\alpha_{0}+\alpha_{1}\left(\frac{1}{A_{t-1}}\right)+\beta\left(\frac{S_{t-1}}{A_{t-1}}\right)+\varepsilon_{t}$

Where,

DISEXP $t_{t}=$ Discretionary expense (the sum of R\&D and SGA) for the period $\mathrm{t}$

$A_{t-1} \quad=$ Total assets at the end of the previous year, $\mathrm{t}-1$

$S_{t-1} \quad=$ Sales for the year $\mathrm{t}-1$

Similar to the other real EM, the abnormal level of discretionary expenses (ADISX) is computed by deducting the normal DISEXP (computed using the estimated coefficients from (3)) from the actual DISEXP. From this, firms, which manage earnings upwards via real EM, would tend to have unusually low cash flows from operations (ASM) and/or low discretionary expenses (ADISX) and/or abnormally high cost of production (APROD). A single variable is created, (RM) by combining the sum ASM (-1), APROD and ADISX(-1).

\section{ACCRUAL-BASED EARNINGS MANAGEMENT (DA)}

This study uses the cross-sectional Jones model (Jones 1991) following Zang (2012). Jones (1991) uses total accruals which can be decomposed into non-discretionary accruals (also known as normal accruals) and discretionary accruals (also known as abnormal accruals). As non-discretionary is compulsory to incur, the focus of detecting EM is on the discretionary portion.

$$
\frac{T A C C_{i t}}{A_{i t-1}}=\alpha_{0}\left[\frac{1}{A_{i t-1}}\right]+\alpha_{1}\left[\frac{\Delta R E V_{i t}}{A_{i t-1}}\right]+\alpha_{2}\left[\frac{G P P E_{i t}}{A_{i t-1}}\right]+\varepsilon_{i t}
$$

Where,

$T A C C_{i t}=$ total accruals measured by net income (before extraordinary items and discontinued operations) - cash flows from operation, in year $t$ for firm $i$

$A_{i t-1} \quad=$ lagged of total asset (year $\mathrm{t}-1$ ) for firm i

$\triangle R E V_{i t}=$ change in sales or revenue (revenues in year $\mathrm{t}-$ revenues in year $\mathrm{t}-1$ ) for firm $\mathrm{i}$

$G P P E_{i t} \quad=$ gross property, plant and equipment in year $\mathrm{t}$ for firm $\mathrm{i}$

$\varepsilon_{i t} \quad=$ residual error (an unexplained component of total accruals) in year $\mathrm{t}$ for firm $\mathrm{i}$

The gross property, plant and equipment (GPPE) and the change in revenue minus the change in trade receivables $\triangle \mathrm{REC}$ is included to control for the non-discretionary accruals portion caused by normal business activities. All variables are deflated by the prior year's total assets to mitigate the problem of heteroscedasticity. The equation is regressed crosssectionally for industry-years, with at least 8 observations. DAC is computed by deducting the NDA (computed using the estimated coefficients from (4)) from the actual total accruals.

\section{FUTURE PERFORMANCE}

This study uses industry-adjusted ROA (adjROAt +1$)$ in measuring the future value of the firms. AdjROA is derived from the difference between firm-specific ROA and the median ROA for the same year and industry.

Gunny (2010) argued that the future firms' value is affected by the firms' current performance, size and growth opportunities, thus needs to be controlled for. As such, the following model is estimated to test whether there is an association between using DA and REM just to meet earnings benchmarks and future performance (Cupertino et al., 2016; Gunny, 2010):

$\operatorname{AdjROA}_{t+1}=\alpha_{0}+\alpha_{1}$ Meet $_{t}+\alpha_{2} E M_{t}+\alpha_{3}$ Meet $^{*} E M_{t}+\alpha_{4} R O A_{t}+\alpha_{5}$Size $_{t}+\alpha_{6} M_{T} B_{t}+\varepsilon_{t}$

Where:

$\operatorname{AdjROA} A_{t+1}=$ industry adjusted ROA for $\mathrm{t}+1$

Meet $=$ an indicator variable set to one, if the net income divided by total assets is between 0 and 0.01 or the change in EPS from $t$ and $t-1$ is between 0 and 0.01 , zero otherwise

Where EM:

$R E M \quad=$ an indicator variable equal set to one if the sum of $\operatorname{ASM}^{*}(-1), \operatorname{ADISX}^{*}(-1)$ and PROD is in the highest quintile, zero otherwise

$D A \quad=$ an indicator variable; set to one, if the DAC is in the highest quintile, zero otherwise

$R O A=$ income before extraordinary items divided by lagged total assets

Size = the natural logarithm of total assets

$M T B=$ the market value of equity divided by the book value of equity 


\section{EMPIRICAL RESULTS}

Based on Table 1 below, the mean (median) value of DAC for the 15-year period is $0.054(0.039)$. The finding of the study is in line with Al-Rassas and Kamardin (2016) and Al-Jaifi (2017), who reported that the mean (median) of 0.056, and 0.060 (0.041), respectively, among Malaysian companies.

TABLE 1. Descriptive statistics

\begin{tabular}{lcccccc}
\hline & Mean & Median & Std. Deviation & $25 \%$ & $75 \%$ & Skewness \\
\hline DAC & 0.054 & 0.039 & 0.053 & 0.017 & 0.073 & 1.925 \\
ASM & 0.008 & 0.007 & 0.076 & -0.036 & 0.054 & -0.074 \\
APROD & 0.013 & 0.016 & 0.118 & -0.046 & 0.071 & 0.162 \\
ADISX & 0.007 & 0.003 & 0.075 & -0.03 & 0.035 & 1.345 \\
RM & 0.028 & 0.03 & 0.217 & -0.083 & 0.14 & 0.259 \\
ROA & 0.044 & 0.042 & 0.075 & 0.013 & 0.079 & -0.058 \\
Size & 5.94 & 5.809 & 1.339 & 4.915 & 6.688 & 0.605 \\
MTB & 1.194 & 0.77 & 1.584 & 0.52 & 1.23 & 4.76 \\
\hline
\end{tabular}

Definition of Variables

DAC = absolute value of abnormal discretionary accruals

ASM = abnormal cash flows*(-1) [sales manipulation]

ADISX = abnormal discretionary expenses * $(-1)$ [discretionary expenses manipulation]

APROD = abnormal production [production manipulation]

RM = sum of $\operatorname{ASM}^{*}(-1), \operatorname{ADISX}^{*}(-1)$ and PROD

ROA $=$ return on assets

Size $\quad=$ natural log of total assets

MTB = market to book value

The RM metrics, on the other hand, have a lower mean (median) value compared to DAC. The mean values are generally lower compared to Western countries (Cohen, Dey, \& Lys 2008; Ferentinou \& Anagnostopoulou 2016; Zang 2012) except for the abnormal production cost (APROD). The mean values in this study for APROD, ADISX, and ASM as a percentage of the lag of total assets are reported at $1.3 \%, 0.7 \%$, and $0.8 \%$, respectively, while the aggregate REM has a mean of $2.8 \%$, respectively. The standard deviations for all the REM proxies are relatively large, indicating that each REM practice for the respective proxies varies widely across firms. The mean ROA for this study is $4.4 \%$, which is slightly higher than $50 \%$ of the sample ROA. The same for Size and MTB where the mean values are reported at 5.94, and 1.194, respectively, while the median values are reported at 5.81 , and 0.77 , respectively.

TABLE 2. Pearson correlation matrix

\begin{tabular}{|c|c|c|c|c|c|c|c|c|c|}
\hline & $\operatorname{AdjROA} A_{t+1}$ & $\mathrm{DA}$ & $\begin{array}{l}\text { Meet* } \\
\text { DA }\end{array}$ & REM & $\begin{array}{l}\text { Meet* } \\
\text { REM }\end{array}$ & Meet & $\mathrm{ROA}$ & Size & MTB \\
\hline \multicolumn{10}{|l|}{$\operatorname{AdjROA}_{t+1}$} \\
\hline DA & $-0.038 * *$ & 1.000 & & & & & & & \\
\hline Meet*DA & -0.002 & $0.312 * * *$ & 1.000 & & & & & & \\
\hline REM & $0.293 * * *$ & -0.016 & -0.010 & 1.000 & & & & & \\
\hline Meet*REM & 0.013 & -0.012 & $0.152 * * *$ & $0.315^{* * *}$ & 1.000 & & & & \\
\hline Meet & $-0.072 * * *$ & $-0.064 * * *$ & $0.349 * * *$ & $-0.060 * * *$ & $0.354 * * *$ & 1.000 & & & \\
\hline ROA & $0.614 * * *$ & $-0.062 * * *$ & 0.000 & $0.302 * * *$ & 0.017 & $-0.062 * * *$ & 1.000 & & \\
\hline Size & $0.238 * * *$ & $-0.106 * * *$ & $-0.0346^{* *}$ & $0.108 * * *$ & 0.008 & $-0.063 * * *$ & $0.275^{* * *}$ & 1.000 & \\
\hline MTB & $0.385 * * *$ & 0.015 & -0.001 & $0.266^{* * *}$ & 0.009 & $-0.076^{* * *}$ & $0.414 * * *$ & $0.172 * * *$ & 1.000 \\
\hline $\operatorname{AdjROA}_{t+1}$ & \multicolumn{9}{|c|}{$=$ industry adjusted $\mathrm{ROA}$ for $\mathrm{t}+1$} \\
\hline Meet & \multicolumn{9}{|c|}{$\begin{array}{l}=\text { an indicator variable set to one, if the net income divided by total assets is between } 0 \text { and } 0.01 \text { or the } \\
\text { change in EPS from } t \text { and } t-1 \text { is between } 0 \text { and } 0.01 \text {, zero otherwise }\end{array}$} \\
\hline DA & \multicolumn{9}{|c|}{$=$ an indicator variable to one, if the DAC from equation 4 is in the highest quintile, zero otherwise } \\
\hline REM & \multicolumn{9}{|c|}{$\begin{array}{l}=\text { an indicator variable equal to one if the sum of } \operatorname{ASM}^{*}(-1), \operatorname{ADISX}^{*}(-1) \text { and APROD is in the highest } \\
\text { quintile, zero otherwise }\end{array}$} \\
\hline
\end{tabular}




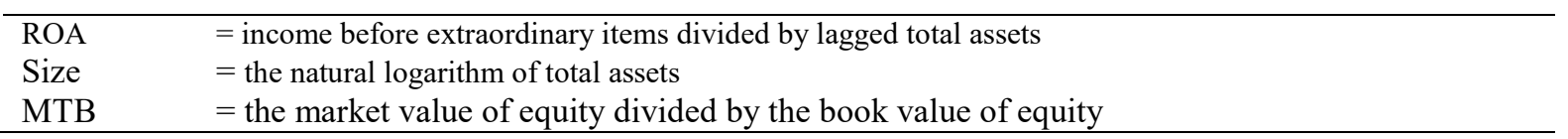

In Table 3, the REM and DA measure the EM and is reported in Model 1 and Model 2, respectively. Based on the regression results, on average, firms that just meet the earnings benchmark (Meet) have lower future performance. This can be seen as both models report a negative coefficient value of $-0.062 \%$ and $0.078 \%$, respectively. More importantly, the coefficient on the interaction terms $($ Meet*EM) in Model 1 of -0.0101 advocates that firms which are involved in REM activities for the purposes to meet earnings benchmarks have significantly lower performance. The result supports the opportunistic view and is consistent with Cupertino et al. (2016); Tabassum et al. (2015). The result can be interpreted by comparing the average future performance of firms that meet the benchmark without engaging in REM of $7.8 \%\left(\alpha_{0}+\alpha_{1}\right)$ with firms that were engaged in EM to meet the earnings benchmark's average future performance of $7.39 \%\left(\alpha_{0}+\alpha_{3}\right)$ (Cupertino et al. 2016). As such, this study's hypothesis is supported where there is a negative relationship between firms that manage earnings (to meet the earnings benchmark) and firms' future performance. This relationship is statistically significant at $10 \%$ level.

TABLE 3. Regressions relating future performance in $\mathrm{t}+1$ to $\mathrm{EM}$

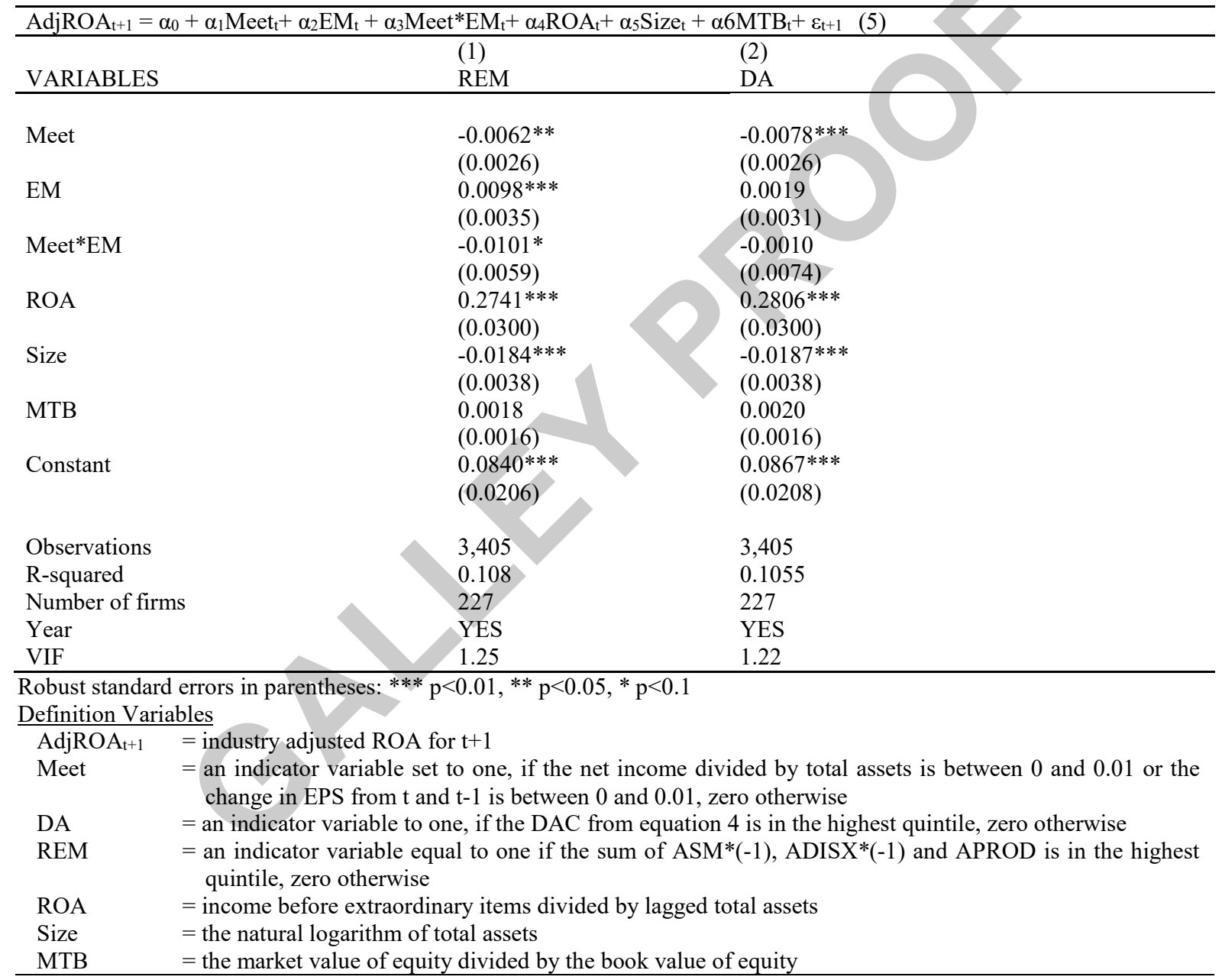

Interestingly the result also finds a significant positive relationship between firms that are involved in REM (not just for meeting the benchmark) with future performance. The finding is consistent with Mohd Suffian et al. (2015) which indicate that these firms have a better future performance when using REM. The average future performance of these firms is $9.38 \%\left(\alpha_{0}+\alpha_{2}\right)$, while firms that are engaged in REM in meeting the earnings benchmark has an average performance of only $7.39 \%$. As such, the result is consistent with the signalling theory, where engaging in REM could be an optimal choice, signalling managerial competence of future firm performance (Al-Shattarat et al. 2018; Bartov et al. 2002; Gunny 2010). However, engaging in REM to just meet the earnings benchmark can be myopic and result in poorer performance (Cupertino et al. 2016).

The results in Model 2 also show a negative relationship between firms engaging in DA (to avoid losses and earnings declines) with future performance, albeit not statistically significant. There is also no association between firms 
that do not just meet the earnings benchmark but engage in DA and future performance. The potential reasons for this could be that the consequences of DA are too small to be detected or it could be due to other reasons, such as, opportunistic and signalling of other information to the market and the combined effect could offset the future performance on average (Gunny 2010).

\section{CONCLUSION}

The advent of modern corporations provides the impetus for the creation of myriads financial reporting issues culminating from diverse financial reporting behaviours arising from capital market forces and economic opportunities. Against the backdrop of this economic related issues, this study empirically investigated, in the Malaysian context, the firms' financial reporting behaviours between 2001 and 2015 and provided evidence that REM led to lower firm's future performance. This, systematically supports the agency theory prediction that firms that engage in REM opportunistically would negatively affect their future performance. However, the same argument does not hold for DA activities. Further, the results also indicate that firms which narrowly meet the earnings benchmark (i.e. avoid losses and earnings decline) have lower future performance. If these firms managed earnings via REM to just meet the earnings benchmark, they will experience an even lower future performance.

Additionally, the results further suggest that firms which either, miss or beat the earnings benchmark, but engage in REM, experience better future performance. This suggests that firms which utilise REM activities to convey private information support the signalling theory. However, no evidence was found for firms which manage earnings via accruals. Thus, the empirical results suggest that different mechanisms of financial reporting behaviours of either discretionary or real based EM provide different implications on the firm's economic success. The paper adds to the growing body of empirical knowledge dealing with financial reporting behaviours and the firm's economic success from the lens of an emerging economy of like Malaysia.

The study has several policy implications for global managers and those in the governance ecosystem. Specifically, the empirical results suggest that different mechanisms of financial reporting behaviours, of either discretionary of real in nature, provide different implications on the firm's future performance. Global managers and governance agents should realise that whilst REM led to lower firm's future performance, it does not hold for DA activities. Firms "just meeting the earnings benchmark" (i.e. avoid losses and earnings decline) will also experience lower future performance. Such lower performance will be further exacerbated if these firms managed earnings via REM just to meet the earnings benchmark. Global managers and governance agents should also understand the strategic motive of firms which either, miss or beat the earnings benchmark, to still engage in REM. The result substantiated that these firms will experience better future performance. This suggests that firms utilise REM activities to convey private information, supporting the signalling theory.

The paper, despite its theoretical and empirical significance, suffers from several limitations which are common in any positivist research. First, this study only uses firms that survived between 2001-2015 periods, against the conditions of meeting the earnings benchmark (i.e. earnings losses and earnings declines), which may not be substantial evidence of EM. Future research could explore other EM dimensions and expand further the scope to include various types of firms, including the financially distressed group to increase the number of observations. Furthermore, measurement errors are commonly associated with EM research. This study, therefore, inherits all the limitations of the models used and acknowledges the need to use several models for the robustness of the results.

\section{REFERENCES}

Ab-Hamid, M. F., Asid, R., Che Sulaiman, N. F., Wan Sulaiman, W. F., \& Abdul Bahri, E. N. 2018. The effect of earnings management on bank efficiency. Asian Journal of Accounting and Governance 10: 73-82.

Abdul Rahim, S., \& Nelson, S. 2018. Directors' Influence on Pay-Based Performance. Asian Journal of Accounting and Governance 9: 11-26.

Adut, D., Holder, A. D., \& Robin, A. 2013. Predictive versus opportunistic earnings management, executive compensation, and firm performance. Journal of Accounting and Public Policy 32(3): 126-146.

Al-Jaifi, H. A. 2017. Ownership concentration, earnings management and stock market liquidity: Evidence from Malaysia. Corporate Governance. The International Journal of Business in Society 17(3): 490-510.

Al-Rassas, A. H., \& Kamardin, H. 2016. Earnings quality and audit attributes in high concentrated ownership market. Corporate Governance 16(2): 377-399.

Al-Shattarat, B., Hussainey, K., \& Al-Shattarat, W. 2018. The impact of abnormal real earnings management to meet earnings benchmarks on future operating performance. International Review of Financial Analysis: 101-264.

Altamuro, J., Beatty, A. L., \& Weber, J. 2005. The effects of accelerated revenue recognition on earnings management and earnings informativeness: Evidence from SEC staff accounting bulletin No. 101. Accounting Review 80(2): 373401.

Arya, A., Glover, J. C., \& Sunder, S. 2003. Are unmanaged earnings always better for shareholders? Accounting Horizons 17: 111-116). 
Ball, R., \& Brown, P. 1968. An Empirical Evaluation of Accounting Income Numbers. Journal of Accounting Research 6(2): 159-178. doi:10.2307/2490232

Bartov, E., Givoly, D., \& Hayn, C. 2002. The rewards to meeting or beating earnings expectations. Journal of Accounting and Economics 33(2): 173-204.

Burgstahler, D., \& Dichev, I. 1997. Earnings management to avoid earnings decreases and losses. Journal of Accounting and Economics 24(1): 99-126.

Chen, C. J. P., \& Jaggi, B. 2000. Association between independent non-executive directors, family control and financial disclosures in Hong Kong. Journal of Accounting and Public Policy 19(4-5): 285-310.

Cohen, D. A., Dey, A., \& Lys, T. Z. 2008. Real and accrual-based earnings management in the pre- and post-Post-SarbanesOxley Periods. The Accounting Review 83(3): 757-787.

Cohen, D. A., \& Zarowin, P. 2010. Accrual-based and real earnings management activities around seasoned equity offerings. Journal of Accounting and Economics 50(1): 2-19.

Cupertino, C. M., Martinez, A. L., \& Costa Jr, N. C. A. d. 2016. Consequences for Future Return with Earnings Management through Real Operating Activities. Revista Contabilidade \& Finanças 27(71): 232-242.

Eldenburg, L. G., Gunny, K. A., Hee, K. W., \& Soderstrom, N. 2011. Earnings Management Using Real Activities: Evidence from Nonprofit Hospitals. The Accounting Review 86(5): 1605-1630.

Embong, Z., \& Hosseini, L. 2018. Analyst forecast accuracy and earnings management. Asian Journal of Accounting and Governance 10: 97-108.

Fama, E. F. 1980. Agency problems and the theory of the firm. Journal of Political Economy 88(2): 288-307.

Ferentinou, A. C., \& Anagnostopoulou, S. C. 2016. Accrual-based and real earnings management before and after IFRS adoption. Journal of Applied Accounting Research 17(1): 2-23.

Gabrielsen, G., Gramlich, J. D., \& Plenborg, T. 2002. Managerial ownership, information content of earnings, and discretionary accruals in a non-US setting. Journal of Business Finance \& Accounting 29(7-8): 967-988.

Gunny, K. A. 2010. The relation between earnings management using real activities manipulation and future performance: Evidence from meeting earnings benchmarks. Contemporary Accounting Research 27(3): 855-888.

Healy, P. M., \& Wahlen, J. M. 1999. A review of the earnings management literature and its implications for standard setting. Accounting Horizons 13(4): 365-383.

Jensen, M. C., \& Meckling, W. H. 1976. Theory of the firm : Managerial behavior, agency costs and ownership structure Journal of Financial Economics 3(4): 305-360.

Jiraporn, P., Miller, G. A., Yoon, S. S., \& Kim, Y. S. 2008. Is earnings management opportunistic or beneficial? An agency theory perspective. International Review of Financial Analysis 17(3): 622-634.

Jones, J. J. 1991. Earnings Management During Import Relief Investigations. Journal of Accounting Research 29(2): 193228.

Jordan, C. E., \& Clark, S. J. 2011. Big Bath Earnings Management: The Case Of Goodwill Impairment Under SFAS No. 142. Journal of Applied Business Research 20(2): 63-70.

Kalgo, S. H., Nordin, B. A. A., Nahar, H. S., \& Turmin, S. Z. 2016. Earnings Quality of Malaysian IPO firms: The Effect of Share Moratorium Provision and Institutional Ownership. Procedia Economics and Finance 35: 107-116.

Kangai, M., Kiremu, G., \& Box, P. O. 2013. Stock Price and Volumes Reaction to Annual Earnings Announcement : A Case of the Nairobi Securities Exchange. International Journal of Business, Humanities and Technology 3(2).

Kim, J. B., \& Sohn, B. C. 2013. Real earnings management and cost of capital. Journal of Accounting and Public Policy 32(6): 518-543.

Kothari, S. P., Mizik, N., \& Roychowdhury, S. 2016. Managing for the moment: The role of earnings management via real activities versus accruals in SEO valuation. Accounting Review 91(2): 559-586.

Kouaib, A., \& Jarboui, A. 2014. External audit quality and ownership structure: Interaction and impact on earnings management of industrial and commercial tunisian sectors. Journal of Economics, Finance and Administrative Science 19(37): 78-89.

Leggett, D. M., Parsons, L. M., \& Reitenga, A. L. 2016. Real earnings management and subsequent operating performance. IUP Journal of Operations Management 15(4): 7-32.

Mlonzi, V. F., Kruger, J., \& Nthoesane, M. G. 2011. Share price reaction to earnings announcement on the JSE-ALtX : A test for market efficiency. South African Busienss Review 15(3): 142-166.

Mohd Suffian, M. T., Mohd Sanusi, Z., \& Matsuki, N. A. 2015. Real earnings management and firm value: Empirical evidence from Malaysia. Malaysian Accounting Review 14(1): 26-47.

Nera, M. M., Manurung, A. H. D. R. M., \& Murwaningsari, E. 2017. The Effects of Earnings Quality, Conservatism, and Real Earnings Management on the Company's Performance and Information Asymmetry as a Moderating Variable. International Journal of Economics and Financial Issues 7(2): 309-318.

Nieken, P., \& Sliwka, D. 2015. Management Changes, Reputation, and "Big Bath"-Earnings Management. Journal of Economics \& Management Strategy 24(3): 501-522.

Omar, N., Rahman, R. A., Danbatta, B. L., \& Sulaiman, S. 2014. Management Disclosure and Earnings Management Practices in Reducing the Implication Risk. Procedia - Social and Behavioral Sciences 145: 88-96. 
Rahman, A. F., Hassan, M. S., Saleh, N. M., \& Shukor, Z. A. 2013. The effect of underinvestment on the relationship between earnings management and information asymmetry. Asian Academy of Management Journal of Accounting and Finance.

Roychowdhury, S. 2006. Earnings management through real activities manipulation. Journal of Accounting and Economics 42(3): 335-370.

Shette, R., Kuntluru, S., \& Korivi, S. R. 2016. Opportunistic earnings management during initial public offerings: evidence from India. Review of Accounting and Finance 15(3): 352-371.

Shu, P.-G., \& Chiang, S.-J. 2014. Firm size, timing, and earnings management of seasoned equity offerings. International Review of Economics \& Finance 29: 177-194.

Skinner, D. J., Sloan, R. G., \& Hand, J. R. M. 2002. Earnings surprises, growth expectations, and stock returns or don't let an earnings torpedo sink your portfolio. Review of Accounting Studies.

Sutrisno, P. 2017. Earnings management: An advantage or disadvantage? Accounting and Finance Review 2(2).

Tabassum, N., Kaleem, A., \& Nazir, M. S. 2015. Real Earnings Management and Future Performance. Global Business Review 16(1): 21-34.

Teoh, S. H., Welch, I., \& Wong, T. J. 1998. Earnings management and the long-run market performance of initial public offerings. The Journal of Finance (6):1935-1974.

Zang, A. Y. 2012. Evidence on the Trade-Off between real activities manipulation and accrual-based earnings management. The Accounting Review 87(2): 675-703.

Nor Irdawati Mahyuddin*

School of Social Sciences

Heriot-Watt University Malaysia

62200 Putrajaya

MALAYSIA

E-mail: n.mahyuddin@hw.ac.uk

Hairul Suhaimi Nahar

Department of Accounting

College of Economics \& Political Science

Sultan Qaboos University Muscat

SULTANATE OF OMAN

E-mail: hairul@squ.edu.om

Yusniyati Yusri

School of Business and Economics

Universiti Putra Malaysia

43400 Serdang Selangor

MALAYSIA

E-mail: atieyy@upm.edu.my

, *Corresponding author 